\title{
Induction of Polyploid Tillered Onion using Colchicine and Pendimethalin
}

(Aruhan Poliploid Bawang Bercelaga menggunakan Kolkisin dan Pendimethalin)

\author{
Jian Ren, Xiaoxu Wu, Ce Song, Yu Liang, WenZheng GaO \& Yong Wang*
}

\begin{abstract}
The shoot tip explants of the tillered onion line Z-018 were used as experimental materials. The effects of colchicine and pendimethalin on the induction of polyploid tillered onion were studied in vitro with different concentrations and treatment time. Treatment with $250 \mu \mathrm{mol} / \mathrm{L}$ colchicine for 4 days caused a variant rate of $42.22 \%$ and a mortality rate of $36.67 \%$, whereas treatment with $30 \mu \mathrm{mol} / \mathrm{L}$ pendimethalin for 6 days caused a variant rate of $41.11 \%$ and a mortality rate of $24.44 \%$. Subsequent cytological identification showed that tetraploid plants were successfully induced by both mutagens. Compared with the diploid plants, the tetraploid plants exhibited slower growth, thicker leaves, stems and roots, larger stomatal apparatus and increased number of chloroplasts. In addition, the obtained tetraploid plants have thicker tubular leaves, decreased number of tillers, larger bulbs and increased yield of the products. This provides the basis for future research on tillered onion germplasm resources.
\end{abstract}

Keywords: Colchicine; germplasm resources; pendimethalin; polyploid induction; tillered onion

\section{ABSTRAK}

Eksplan hujung pucuk bawang bercelaga titisan Z-018 telah digunakan sebagai bahan uji kaji. Kesan daripada kolkisin dan pendimetalin ke atas aruhan poliploid bawang bercelaga telah dikaji secara in vitro dengan kepekatan dan masa rawatan yang berbeza. Rawatan dengan $250 \mu \mathrm{mol} / \mathrm{L}$ kolkisin selama 4 hari menyebabkan kadar varian $42.22 \%$ dan kadar kematian 36.67\%, manakala rawatan dengan 30 umol/L pendimetalin selama 6 hari menyebabkan kadar varian $41.11 \%$ dan kadar kematian sebanyak $24.44 \%$. Pengenalan sitologi selanjutnya menunjukkan bahawa tumbuhan tetraploid telah berjaya diaruh oleh kedua-dua mutagen. Berbanding dengan tumbuhan diploid, tumbuhan tetraploid menunjukkan pertumbuhan yang lebih perlahan, daun, batang dan akar yang lebih tebal, peralatan stomatal yang lebih besar dan peningkatan bilangan kloroplas. Selain itu, tumbuhan tetraploid yang diperoleh mempunyai tiub daun lebih tebal, bilangan celaga yang berkurangan, bebawang yang lebih besar dan peningkatan hasil keluaran. Kajian ini menyediakan sumber asas untuk penyelidikan germplasma bawang bercelaga pada masa hadapan.

Kata kunci: Aruhan poliploid; bawang bercelaga; kolkisin; pendimethalin; sumber germplasma

\section{INTRODUCTION}

Tillered onion (Allium cepa L. var. aggregatum G. Don) is a variant of the onion (Allium cepa), with characteristics of brass color, long storage duration, cold tolerance, and short growth cycle (Zhai et al. 2013). It is usually cropped with Chinese cabbage in high latitude regions to improve the land usage (Xu et al. 2016). The vegetative breeding of tillered onion is mainly through the tiller bulb (Zhang 2013). Few of them may be bolted and flowered but are difficult to be used (Liu et al. 2011). The phenotypes of the offspring of tillered onion are similar to those of lithophytic plants, which makes it difficult to select good traits. Therefore, the innovation of tillered onion germplasm resources is very limited.

Polyploidy is the presence of more than two sets of chromosomes above the diploid level in the nucleus of the cells of an organism (Comai 2005; Leitch \& Bennett 1997). Polyploid cells are significantly larger than their diploid progenitors (Beaulieu et al. 2008) and polyploid plants usually present bigger organs (flowers and leaves), an intensification of colors, thicker and more rigid foliage and an increase in disease resistance (Callaway 2000). Polyploid breeding may enhance the resistance of crops and improve the quality and yield of crop products and is thus an important way to create new crop germplasm.

Colchicine is a widely used chemical mutagen in induction of polyploid animals and plants (Kermani et al. 2003; Kunitake et al. 1998; Nigel et al. 2007). Many studies have shown that the affinity of colchicine for plant tubulin is much lower than that of animal tubulin. Therefore, high concentrations of colchicine for chromosome doubling of plant cells are necessary, causing greater toxicity to plant materials (Morejohn et al. 1987). Besides colchicine (Liu et al.2010), herbicide mutagens such as pendimethalin are gaining more and more attentions and this type of herbicide has been successfully used to obtain polyploid in garlic (Zhou et al. 2009), P. tomentosa $\times$ P. bolleana (Huang et al. 2002) and Zantedeschia aethiopica (Zhang et al. 2008).

Tillered onion has the characteristics of cold tolerance, short growth period (80-90 days) and strong adaptability 
to different environmental conditions and its nutritional value is even higher than that of common onion (Jin et al. 2013; Zhao et al. 2015). Tillered onion can be planted in high latitude areas where common onion cannot grow. However, it is not well studied because of its small planting area and innovation of its germplasm resources is still lacking. In this study, we successfully induced tetraploid tillered onion plants by treating the shoot tip explants with colchicine and pendimethalin in vitro and obtained excellent germplasm resources of tillered onion through horticultural characterization.

\section{MATERIALS AND METHODS}

Tillered onion line Z-018 was used as the experimental materials, which was provided by the Key Laboratory of Biology and Genetic Improvement of Horticultural Crops, Ministry of Agriculture, Northeast Agricultural University. After peeling the skin and rinsing with tap water, the top $1 / 3$ portion of the bulb was removed and incubated at $70^{\circ} \mathrm{C}$ for $10 \mathrm{~min}$. The explant was subsequently soaked in $10 \%$ $\mathrm{NaClO}$ solution for $10 \mathrm{~min}$, washed with sterile water four times and dried on sterile filter paper. The 0.15-0.3 $\mathrm{mm}$ tip was then cut with tweezers and anatomical needle under sterile conditions and inoculated on a MS medium supplemented with $0.1 \mathrm{mg} / \mathrm{L} 2$-IP and $0.1 \mathrm{mg} / \mathrm{L}$ NAA. A culture condition conducive to the expansion of the bulb was used as follows: $25 \pm 1^{\circ} \mathrm{C}$ temperature, 2000 lux light intensity and $13 \mathrm{~h} /$ day photoperiod.

\section{COLCHICINE AND PENDIMETHALIN TREATMENT}

Under sterile condition, the shoot tips were placed on the medium containing either colchicine or pendimethalin and cultured in dark for 2, 4 and 6 days, respectively. The control group was treated with sterile water for 4 days. 30 shoot tips were treated for each group and each treatment was repeated three times. Three different concentrations were used for each mutagen (colchicine: 250, 750 and 1250 $\mu \mathrm{mol} / \mathrm{L}$; pendimethalin: 10,30 and $50 \mu \mathrm{mol} / \mathrm{L}$ ). At the end of the treatment, the shoot tips were transferred onto fresh medium without the mutagens. The survival rate and the variation of regenerated plants were investigated after 40 days in culture.

\section{LEAF STOMATA CHARACTERIZATION}

The mature leaves of the diploid and variant plants at the same growth stage were used to examine the leaf stomata using fluorescence microscopy at $20 \times 40$ magnification. Leaf length, leaf width and leaf shape were measured using a US-made CI-202 portable leaf area analyzer. The density of stomata and the length and width of guard cells were calculated and compared between diploid and variant plants. The number of stomata was averaged from 30 view fields and the length and width of guard cells were measured and averaged from 30 cells. At the same time, the number of chloroplasts in the stomatal guard cells was counted. If the chloroplasts in the stomata overlap or the adhesion were not easy to count, they will not be counted. Each experiments were repeated three times.

\section{CHROMOSOME NUMBER DETERMINATION}

The chromosome number was determined under an OLYMPUS microscope according to a root tip chromosome preparation method (Zhang \& Dai 2007).

\section{FLOW CYTOMETRY}

The FACSAria automatic double laser four-color flow cytometric sorting system was used to determine the relative content of DNA in leaves. FL2 channel was used to detect the fluorescence intensity. Data were analyzed with the random software Cell Qest ProTM and graphed via Summit v4.0 software (Endang \& Yosuke 2003).

\section{HORTICULTURAL TRAITS OF THE OFFSPRING}

The obtained tetraploid plants were transplanted into the vegetarian bowl in 2012 and placed in a greenhouse and the adult bulbs were harvested the same year. The bulbs from different lines were numbered and planted in the subsequent three years. Lines with excellent traits were screened based on the agronomic characters such as leaf color, leaf roughness, wax powder and bulb size.

\section{DATA PROCESSING}

Data were obtained and averaged from the 3 years of survey and analyzed using DPS (version 9.5) software.

\section{RESULTS AND DISCUSSION}

\section{EFFECT OF COLCHICINE AND PENDIMETHALIN ON INDUCTION OF TILLERED ONION VARIATION}

The shoot tips were treated with different concentrations of colchicine and pendimethalin. Table 1 shows that treatment with $250 \mu \mathrm{mol} / \mathrm{L}$ colchicine for 2 days resulted in a mortality rate of $27.78 \%$ and the mortality rate was increased to $94.44 \%$ when treated with $1250 \mu \mathrm{mol} / \mathrm{L}$ colchicine for 6 days, indicating that high concentration of colchicine and long treatment time significantly inhibited shoot tip differentiation and growth. The mortality rate of the shoot tip explants increases as the colchicine concentration and the treatment time increases. Treatment with $250 \mu \mathrm{mol} / \mathrm{L}$ colchicine for 4 days appeared to be the best condition, with a variant rate of $42.22 \%$ and a mortality rate of $36.67 \% .38$ variants were obtained from this treatment. In comparison, the toxicity of pendimethalin is significantly lower than that of colchicine, although the variants rate was also lower. In general, higher concentrations and longer treatment time are beneficial for shoot tips variation. We obtained 37 variant plants from the groups of $30 \mu \mathrm{mol} / \mathrm{L}$ pendimethalin treatment for 6 days, with a variant rate of $41.11 \%$ and a mortality rate of $24.44 \%$. A total of 149 
TABLE 1. Effects of colchicine and pendimethalin treatment on shoot tips

\begin{tabular}{lccccccc}
\hline Treatment & $\begin{array}{c}\text { Concentration } \\
(\mu \mathrm{mol} / \mathrm{L})\end{array}$ & $\begin{array}{c}\text { Duration } \\
(\mathrm{d})\end{array}$ & Numbers & Deaths & Mortality $(\%)$ & Variants & Rate $(\%)$ \\
\hline CK & 0 & 4 & 90 & 0 & 0 & 0 & 0 \\
\hline Colchicine & 250 & 2 & 90 & 25 & $27.78 \pm 1.15 \mathrm{f}$ & 18 & $20 \pm 1.00 \mathrm{c}$ \\
& 250 & 4 & 90 & 37 & $41.11 \pm 0.58 \mathrm{e}$ & 38 & $42.22 \pm 2.52 \mathrm{a}$ \\
& 250 & 6 & 90 & 43 & $47.78 \pm 0.58 \mathrm{~d}$ & 27 & $30 \pm 1.00 \mathrm{~b}$ \\
& 750 & 2 & 90 & 55 & $61.11 \pm 0.58 \mathrm{c}$ & 11 & $12.22 \pm 1.53 \mathrm{cde}$ \\
& 750 & 4 & 90 & 58 & $64.44 \pm 0.58 \mathrm{c}$ & 13 & $14.44 \pm 1.53 \mathrm{cde}$ \\
& 750 & 6 & 90 & 83 & $92.22 \pm 0.58 \mathrm{a}$ & 6 & $6.67 \pm 1.00 \mathrm{de}$ \\
& 1250 & 2 & 90 & 67 & $74.44 \pm 0.58 \mathrm{~b}$ & 15 & $16.67 \pm 2.00 \mathrm{~cd}$ \\
Total & 1250 & 4 & 90 & 68 & $75.56 \pm 2.08 \mathrm{~b}$ & 17 & $18.89 \pm 2.08 \mathrm{c}$ \\
\hline Pendimethalin & 1250 & 6 & 90 & 85 & $94.44 \pm 1.53 \mathrm{a}$ & 4 & $4.44 \pm 1.15 \mathrm{e}$ \\
& & & & & 149 & $33.33 \pm 1.10 \mathrm{bcd}$ \\
& 10 & 2 & 90 & 7 & $7.78 \pm 0.59 \mathrm{a}$ & 30 & $38.89 \pm 0.58 \mathrm{ab}$ \\
& 10 & 4 & 90 & 10 & $11.11 \pm 0.61 \mathrm{a}$ & 35 & $31.11 \pm 1.05 \mathrm{cde}$ \\
& 10 & 6 & 90 & 15 & $16.67 \pm 1.07 \mathrm{a}$ & 28 & $27.78 \pm 0.62 \mathrm{de}$ \\
& 30 & 2 & 90 & 14 & $15.56 \pm 0.62 \mathrm{a}$ & 25 & $34.44 \pm 1.59 \mathrm{bc}$ \\
& 30 & 4 & 90 & 18 & $20 \pm 1.09 \mathrm{a}$ & 31 & $41.11 \pm 0.63 \mathrm{a}$ \\
& 6 & 90 & 22 & $24.44 \pm 0.60 \mathrm{~b}$ & 37 & $30 \pm 1.10 \mathrm{cde}$ \\
& 30 & 2 & 90 & 19 & $21.11 \pm 0.61 \mathrm{c}$ & 27 & $18.89 \pm 0.62 \mathrm{f}$ \\
\end{tabular}

Each group was treated with 30 lines. The treatment was repeated for three times, and the Duncan range test was used. Lower-case letters indicate the significant difference at 0.05 level

variant plants were obtained from colchicine treatment and 252 from pendimethalin treatment. These results suggest that, compared with colchicine, pendimethalin has the advantage of low toxicity and low cost in inducing polyploid variants of tillered onion.

\section{IDENTIFICATION OF POLYPLOID PLANTS}

The variant plants were transferred to $1 / 2 \mathrm{MS}$ medium for observation and identification. Morphological traits of variant plants were most obvious in leaves and roots. The leaf length of the variants was decreased to $83.65 \%$ of the diploids; the leaf width was increased to $124.03 \%$ of the diploid plants; and the leaf index was only $61.82 \%$ of the diploid plants. The value of the above three parameters of the variant plants all reached a very significant difference level compared with those of the diploid plants. In addition, the variant plants showed other morphological changes, including thicker and sometimes slightly twisted leaves with a slightly rough surface, a darker color of the leaves, more purple colors in the bulb and hypertrophic roots (Figure $1 \&$ Table 2).

We examined the leaf stomata of the variant plants and found that the lower epidermal guard cells of the leaves were larger than those of the diploid plants, but the density was decreased (Figure $2 \&$ Table 3 ). The vertical diameter of stomata increased to $149.88 \%$ of the diploids and the transverse diameter of stomata increased to $124.60 \%$ of the diploids. The number of chloroplasts in guard cells of variant plants was also increased to

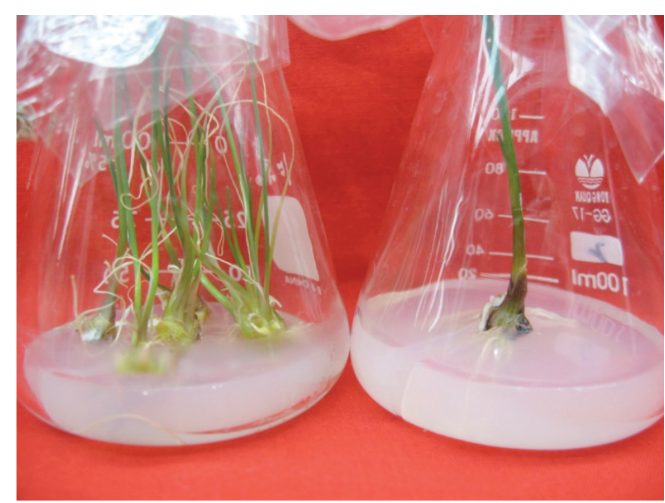

A

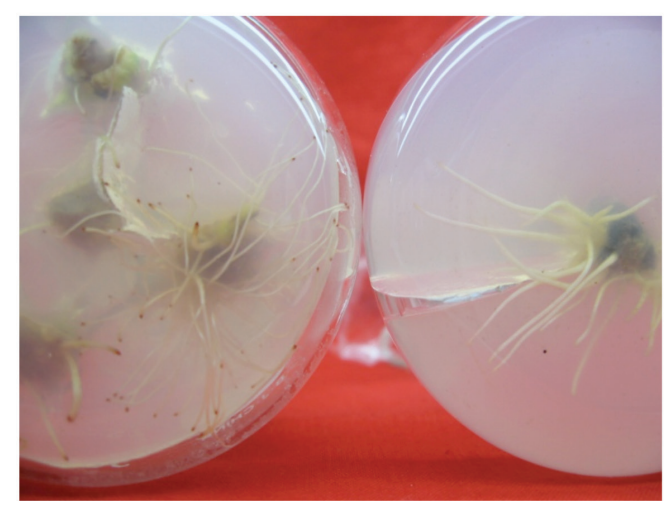

B

FIGURE 1. Comparison of the photographs of diploids and variants. (A) leaves (left: diploids and right: variants), and (B) roots (left: diploids and right: variants) 
TABLE 2. Comparison of the morphological characteristics of diploids and variants

\begin{tabular}{lccc}
\hline Ploidy & Leaf length $(\mathrm{cm})$ & Leaf width $(\mathrm{mm})$ & Leaf index \\
\hline Diploids & $6.24 \pm 0.60 \mathrm{a}$ & $2.32 \pm 0.35 \mathrm{a}$ & $29.41 \pm 0.44 \mathrm{a}$ \\
Variants & $5.22 \pm 0.41 \mathrm{a}$ & $2.91 \pm 0.29 \mathrm{a}$ & $18.18 \pm 0.40 \mathrm{~b}$ \\
\hline
\end{tabular}

The treatment was repeated for three times, and the Duncan range test was used. Lower-case letters indicate the significant difference at 0.05 level

$175.86 \%$ of the diploids. The density of stomata was decreased to $50.41 \%$ of the diploids. Statistical analysis showed that the length, width, guard cell area, chloroplast number in guard cells and stomatal density of variant plants were all significantly different from those of the

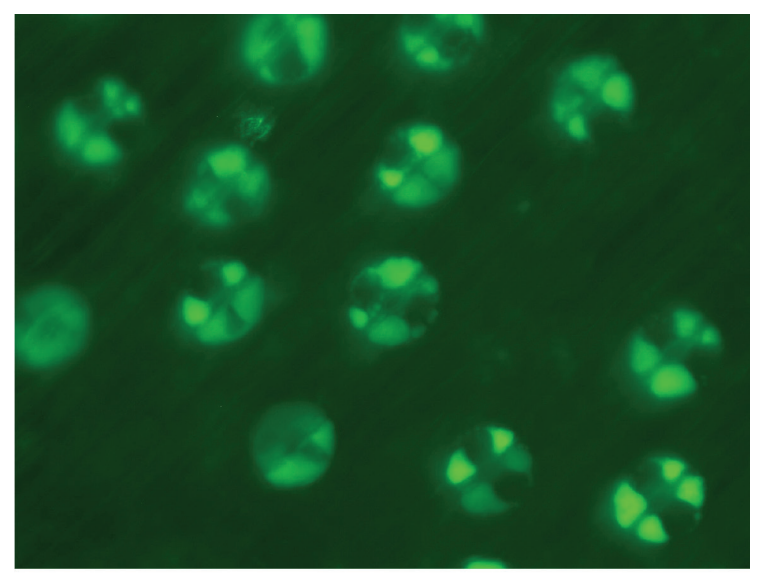

A

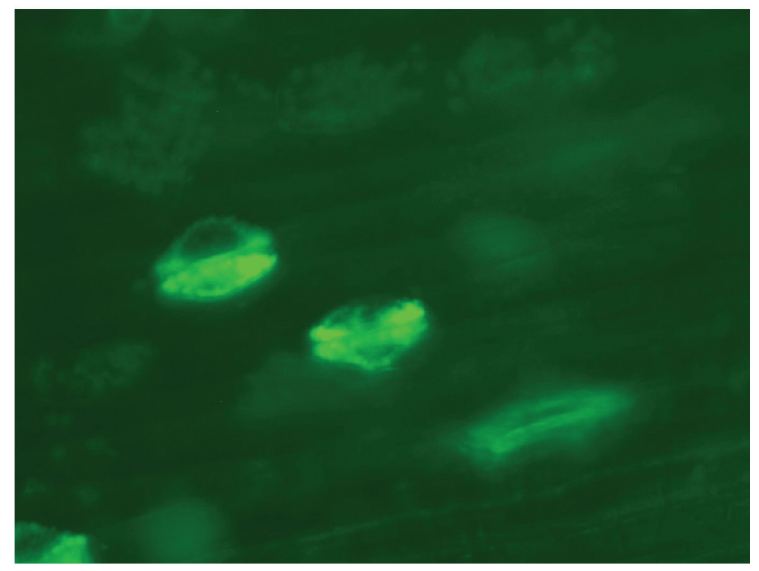

B

FIGURE 2. Compared photographs of guard cells of diploids (A) and variants (B) diploids, suggesting that these are important traits of variant plants and may be used to distinguish variant plants form the diploids. We obtained 121 suspected polyploid plants from 401 variant plants by comparing the stomatal and guarded cells. Among them, 57 were induced by colchicine, the mutation rate was $38.26 \%$ and 64 were induced by pendimethalin, the mutation rate was $25.40 \%$, indicating that although the lethal rate of pendimethalin was low, the false positive rate was also high.

The apical part of the suspected polyploid plants was used in pressing plate method to determine the number of chromosomes. Tillered onion is a diploid plant with the number of chromosomes of $2 n=2 \times=16$. The variant plants showed altered number of chromosomes, with most of them having $2 n=4 \times=32$ chromosomes (Figure 3 ), suggesting that they were tetraploid plants. Some of the variant plants were chimeras, with both $2 \times$ and $4 \times$ cells. In addition, a few variant plants appeared to be octaploid plants with $2 \mathrm{n}=8 \times=64$ chromosomes, which probably resulted from a doubling of the induced tetraploid plants. Among the 401 variant plants, the number of plants with ploidy changed by observing in chromosome pressing plate method was 121 , of which 85 were tetraploid, accounting for $57.04 \%$ of the total variation and $70.25 \%$ of the ploidy mutant. Out of these 85 tetraploids, 40 were from colchicine induction and the remaining 45 were from pendimethalin induction. Three octoploid materials were all induced by colchicine. 33 plants were chimeras, 14 were induced by colchicine and 19 were induced by pendimethalin.

The nucleic acid was extracted from the polyploid plants and the ploidy was further determined by flow cytometry. As shown in Figure 4 the abscissa PI-A value represents the channel value of the fluorescence and the ordinate Count represents the relative value of the measured cell number. The peak position can be seen as the ploidy of the test sample. The relative content of the diploids DNA (the highest peak) was around 50 and the

TABLE 3. Comparison of the leaf characteristics of diploids and variants

\begin{tabular}{lccccc}
\hline Ploidy & $\begin{array}{c}\text { Guard cell length } \\
(\mu \mathrm{m})\end{array}$ & $\begin{array}{c}\text { Guard cell width } \\
(\mu \mathrm{m})\end{array}$ & $\begin{array}{c}\text { Guard cell area } \\
\left(\mu \mathrm{m}^{2}\right)\end{array}$ & $\begin{array}{c}\text { No. of stomata } \\
(20 \times 40)\end{array}$ & $\begin{array}{c}\text { Chloroplast } \\
\text { number }\end{array}$ \\
\hline Diploids & $41.41 \pm 1.05 \mathrm{~b}$ & $32.76 \pm 1.88 \mathrm{~b}$ & $1189.55 \pm 0.39 \mathrm{~b}$ & $8.93 \pm 0.59 \mathrm{a}$ & $5.54 \pm 0.60 \mathrm{~b}$ \\
Variants & $61.42 \pm 1.25 \mathrm{a}$ & $41.84 \pm 1.41 \mathrm{a}$ & $2355.75 \pm 0.32 \mathrm{a}$ & $4.75 \pm 0.62 \mathrm{~b}$ & $11.36 \pm 0.61 \mathrm{a}$ \\
\hline
\end{tabular}

The treatment was repeated for three times, and the Duncan range test was used. Lower-case letters indicate the significant difference at 0.05 level 

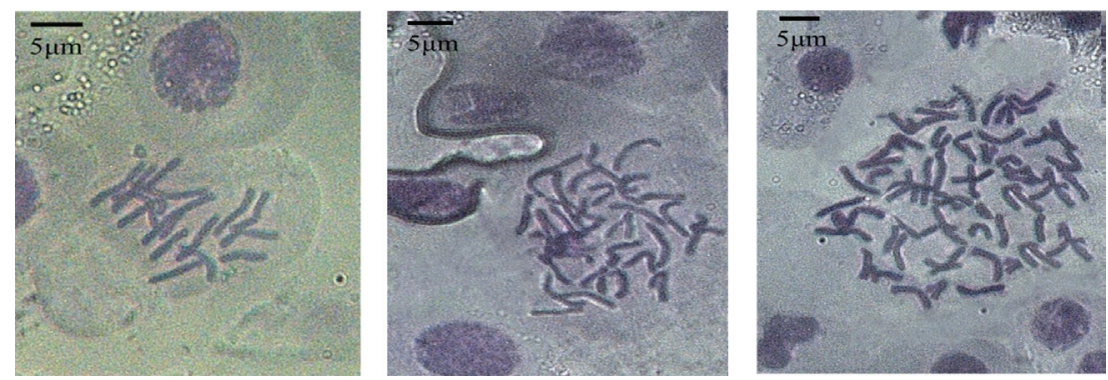

FIGURE 3. Comparison of number of root tip chromosome of diploids and variants. (A) diploids $2 n=2 x=16,(B)$ tetraploid $2 n=4 x=32$ and $(C)$ octoploid $2 n=8 x=64$
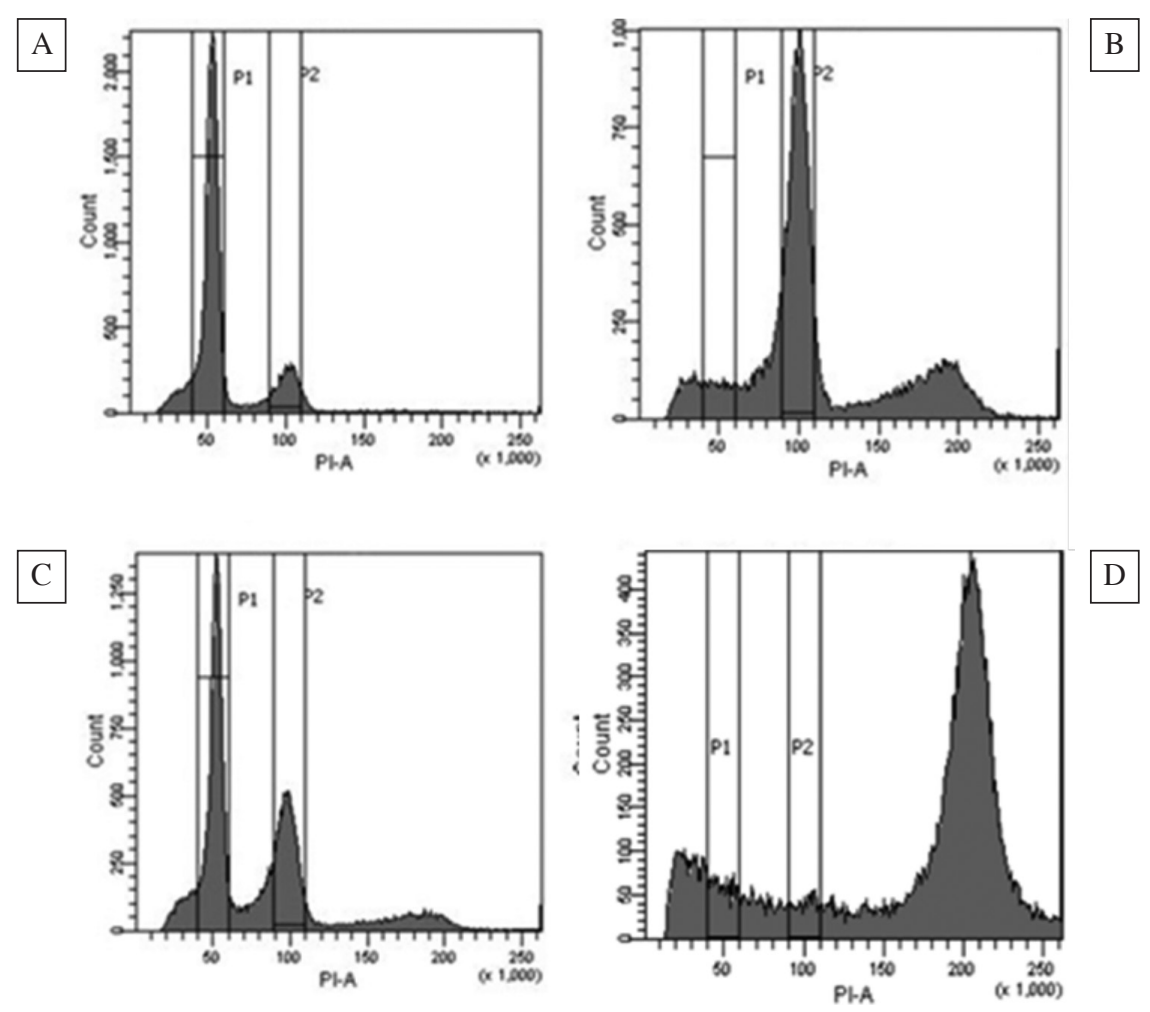

FIGURE 4. Fuzzy cognitive map ploidy analysis diagram. (A) diploid,

(B) tetraploid, (C) aneuploidy and (D) octoploid

relative content of suspected tetraploid DNA was around 100. Some samples had three peaks of the relative content of DNA around 50 and 100, with a diploid ratio of 1 to 2, indicating that they are chimeras.

These results were consistent with those obtained from the pressing plate method. Based on the results of chromosome pressing plate method and flow cytometry, the chimeras in the polyploid plants accounted for a large proportion. Moreover, the proportion of polyploid cells in the chimeras decreased as the plants grow, and some of the chimeras containing polyploid cells even restored to diploid at a late growth stage. Therefore, to obtain more polyploid plants, chimeras should be separated in time. Chimeric tissue can be cultured and differentiated into adventitious buds, from which stable polyploid plants can be separated and purified (Burge et al. 2002).

\section{PHENOTYPIC ANALYSIS OF OFFSPRING OF POLYPLOID PLANTS}

After three consecutive years of planting and observation, we found that most of the tetraploid plants (85) became similar to the diploid plants. Only seven lines (tr-1, tr$5, \operatorname{tr}-7, \operatorname{tr}-17, \operatorname{tr}-31, \operatorname{tr}-42$ and tr-73) were still different from the original line $\mathrm{Z}-018$. Tr- $1, \operatorname{tr}-5, \operatorname{tr}-7$ and $\operatorname{tr}-17$ were induced by colchicine and the other three materials were derived from pendimethalin induction. These lines showed significantly stronger growth potential than Z-018. Specifically, they had increased plant height and leaf length and thicker tubular leaf and cauloid. Although the number of tillers per plant was decreased, the weight of single bulbs was increased, with a maximum weight of $9.17 \mathrm{~g}$, which are the characteristics of polyploid plants and the phenotype of the polyploid offspring was 


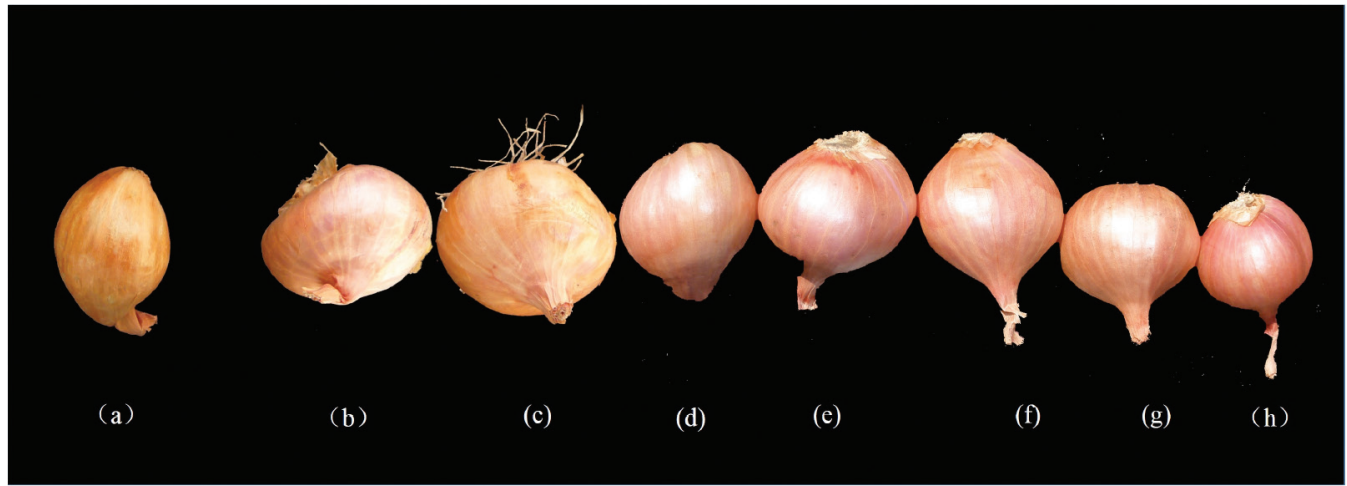

FIGURE 5. Phenotypic comparison of single bulb in diploid and tetraploid lines.

(a) diploid line Z-018 and (b-h) tetraploid lines tr-1, tr-3, tr-5, tr-17, tr-31, tr-42 and tr-73

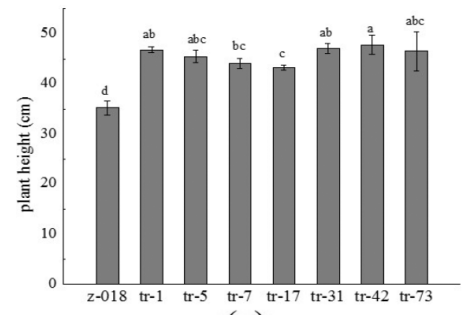

(a)

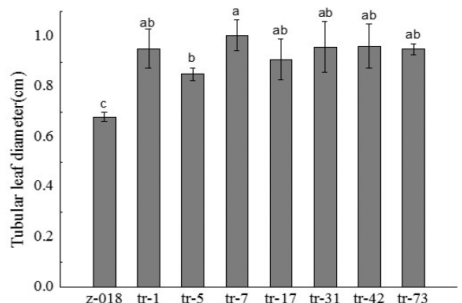

(c)

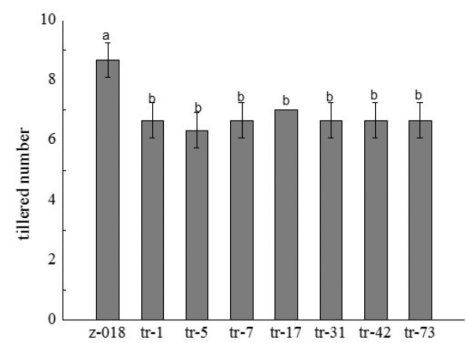

(e)

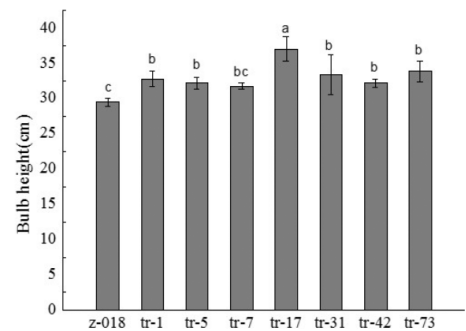

(g)

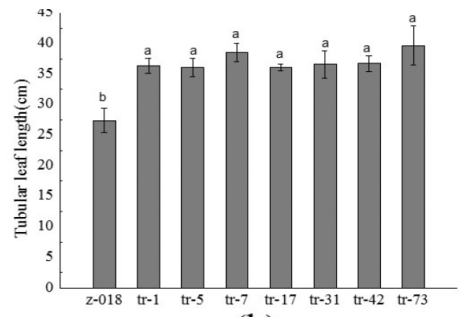

(b)

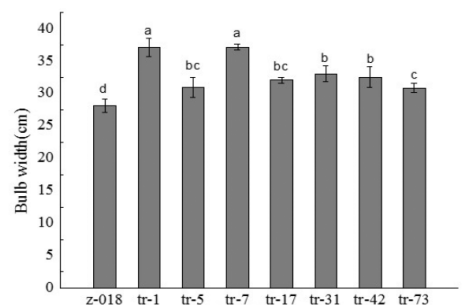

(d)

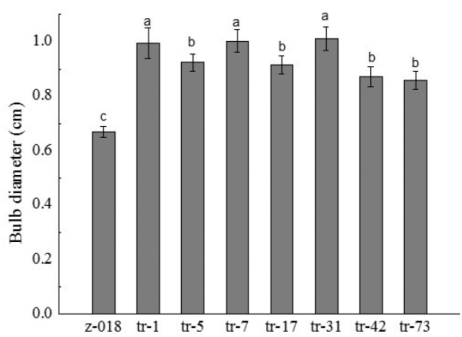

(f)

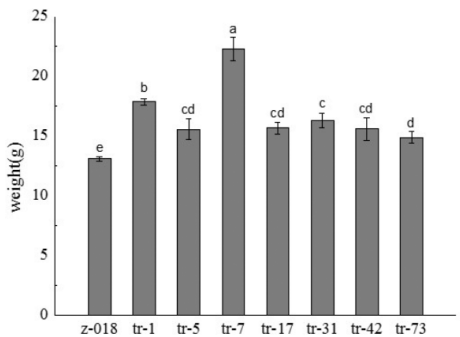

(h)

FIGURE 6. Comparison of the difference between Z-018 line and tetraploid lines.

(a) plant height, (b) tubular leaf length, (c) tubular leaf stems, (d) bulb width, (e) number of tiller,

(f) bulb width, (g) bulb height and (h) bulb weight 
not related to the type of inducer (Figures $5 \& 6$ ). Since the total yield of tillered onion is determined by both the number of tillers and the weight of single bulb, which were negatively correlated, plants with six or seven tillers usually produced better yield. Although the number of tillers of the obtained polyploid plants was reduced, the yield was actually increased.

\section{CONCLUSION}

In this experiment, the effects of colchicine and pendimethalin on the induction of polyploid tillered onion were studied in vitro with different concentrations and treatment time. The results showed that the tiller onion was more sensitive to pendimethalin than colchicine. The difference between them in variant was not significant, but the difference in mortality was significant. Taking into account the mutation rate and mortality rate, pendimethalin is an undoubtedly suitable inducer to completely replace colchicine. Subsequent cytological identification showed that tetraploid plants were successfully induced by both mutagens. Compared with the diploid plants, the tetraploid plants exhibited slower growth, thicker leaves, stems and roots, larger stomatal apparatus and increased number of chloroplasts. In addition, the obtained tetraploid plants had thicker tubular leaves, decreased number of tillers, larger bulbs and increased yield of the products. Ploidy variation is a very useful method for innovation of germplasm resources for vegetative breeding plants. The use of tillered onion high-frequency regeneration system to create a polyploid plants not only provides a richer germplasm resource for the breeding of tillered onion but also has high induction rate, and the chimera rate is low to a certain extent.

\section{ACKNOWLEDGEMENTS}

This work was supported by Heilongjiang Province vegetable industry technology collaborative innovation system (HNWSCTX201701). Both Jian Ren and Xiaoxu Wu contributed equally to this work and should be considered co-first authors.

\section{REFERENCES}

Beaulieu, J.M., Leitch, I.J., Patel, S., Pendharkar, A. \& Knight, C.A. 2008. Genome size is a strong predictor of cell size and stomatal density in angiosperms. New Phytologist 179(4): 975-986

Burge, G.K., Morgan, E.R. \& Seelye, J.F. 2002. Opportunities for synthetic plant chimeral breeding: Past and future. Plant Cell Tissue \& Organ Culture 70(1): 13-21.

Callaway, D.J. \& Callaway, M.B. 2000. Breeding Ornamental Plants. Portland: Timber Press.

Comai, L. 2005. The advantages and disadvantages of being polyploid. Nature Reviews Genetics 6(11): 836-846.

Endang, S. \& Yosuke, T. 2003. Determination of ploidy levels of shallot and Japanese bunching onion by flow cytometry. Ilmu Pertanian 10(1): 9-15.
Huang, Q.,Zhang, Z.\& Kang, X.2002.2n pollen of P.tomentosa * P. bolleana induced by four antimicrotubule agents. Journal of Beijing Forestry University 24(1): 12-15.

Jin, X., Zhou, X., Liu, S., Liu, S. \& Wu, F. 2013. ISSR markers of 48 tillering onion (Allium cepa var. aggregatum) germplasms genetic diversity and analysis of their agronomic traits. China Vegetables 1(1x): 27-34.

Kermani, M.J., Sarasan, V., Roberts, A.V., Yokoya, K., Wentworth, J. \& Sieber, V.K. 2003. Oryzalin-induced chromosome doubling in Rosa and its effect on plant morphology and pollen viability. Theoretical and Applied Genetics 107(7): 1195-1200.

Kunitake, H., Nakashima, T., Mori, K. \& Tanaka, M. 1998. Somaclonal and chromosomal effects of genotype, ploidy and culture duration in Asparagus officinalis L. Euphytica 102(3): 309-316.

Leitch, I.J. \& Bennett, M.D. 1997. Polyploidy in angiosperms. Trends in Plant Science 2: 470-476.

Liu, W., Ning, S., Cui, C., Xu, Q. \& Ma, Y. 2011. Effect of gibberellin treatment on growth and development of tilleredonion. Journal of Northeast Agricultural University (7): 83-86.

Liu, X., Wang, D., Yang, W. \& Zhang, J. 2010. Polyploidy induction of aigeiros-luece hybrids of Populus by colchicine. Journal of Anhui Agricultural Sciences 38(20): 10532-10534.

Morejohn, L.C., Bureau, T.E., Molè-Bajer, J., Bajer, A.S. \& Fosket, D.E. 1987. Oryzalin, a dinitroaniline herbicide, binds to plant tubulin and inhibits microtubule polymerization in vitro. Planta 172(2): 252-264.

Nigel, A.R.U., Jennie, H. \& Therese, M. 2007. Generation and characterization of colchicine-induced autotetraploid Lavandula angustifolia. Euphytica 156: 257-266.

Xu, L., Yang, F., Wu, X., Ding, R., Lu, Y. \& Hou, B. 2016. Effect of intercropping with onion or garlic on yield and quality of Chinese cabbage. Northern Horticulture (14): 6-10.

Zhai, Y., Ma, R., Cheng, Y. \& Wu, H. 2013. Research progress on genetic diversity of germplasm resources of Allium cepa L. Journal of Agriculture 3(6): 61-63.

Zhang, D. 2013. Vegetable history tillering onion. China Vegetables 10: 26-26.

Zhang, W. \& Dai, Z. 2007. The experiment of onion root tip mitosis specimen preparation and observation. Genetics Experiment Guidance. Beijing: Higher Education Press.

Zhang, X., Hong-Zhi, W.U., Zhou, D. \& Zheng, S. 2008. Effects of the new herbicide-oryzalin's concentration and time duration on inducing polyploidy of coloured Zantedeschia aethiopica. Journal of Yunnan Agricultural University 23(6): 806-810.

Zhao, J., Song, S., Han, Y., Zhao, C., Zhang, X. \& Zhang, Y. 2015. Comparative analysis of nutritional quality between Allium cepa $\mathrm{L}$. var. agrogatum Don. and Allium cepa L. Journal of Northwest A \& F University 43: 107-110.

Zhou, X., Cheng, Z. \& Meng, H. 2009. Effects of pendimethalin on garlic chromosome doubling in vitro. Acta Botanica Boreali-Occidentalia Sinica 29(12): 2571-2575.

Jian Ren, Xiaoxu Wu, Ce Song, Yu Liang, Wenzheng Gao \& Yong Wang*

College of Horticulture and Landscape Architecture

Northeast Agricultural University

Harbin 150030

China 
Jian Ren, Xiaoxu Wu, Ce Song, Yu Liang, Wenzheng Gao \& Yong Wang*

Key Laboratory of Biology and Genetic Improvement of Horticultural Crops (Northeast Region)

Ministry of Agriculture

Northeast Agricultural University

Harbin 150030

China
*Corresponding author; email: yongwang@neau.edu.cn

Received: 20 February 2018

Accepted: 29 June 2018 